\title{
Pleural radiation-induced sarcoma: a SEER population-based description of a rare entity
}

\author{
Pierre Loap, Youlia Kirova \\ Institute Curie, Department of Radiation Oncology, Paris, France
}

Key words: radiation-induced sarcoma; pleural sarcoma; SEER database

Rep Pract Oncol Radiother 2021;26(2):318-319

\section{Dear Editor,}

Radiation-induced sarcomas (RIS) represent rare complications of radiation therapy but their prognosis is poor. The consensual definition was first proposed by Cahan in 1948 [1] based on prior history of radiation therapy and occurrence of a histologically-proven sarcoma within the irradiation fields after a latency period longer than five years. The pleura is made of tissues of diverse histological origin (mesothelium and connective tissues, such as blood or lymphatic vessels) explaining the diversity of radiation-induced pleural side-effects, such as effusion, thickening or mesothelioma. Yet, pleural RIS have never been evaluated in epidemiological studies. We aimed to better understand the characteristics of pleural RIS based on the SEER Program cancer registry.

\section{SEER registry analysis}

Pleural sarcomas were identified in the SEER 18-registry database (1973-2015), using the SEER ${ }^{\star}$ STAT software (version 8.3.6) for data extraction. Identification was based on biopsy-proven sarcoma histology (classified as "IX Soft tissue and other extraosseous sarcomas", according to the Classification for International Classification for Childhood Cancer Recode ICD-O-3/World Health
Organization 2008), on pleural primary localization (classified as "C-38.4-Pleura", according to the International Classification of Diseases, 10th Revision, Clinical Modification (ICD-10-CM) classification system) and on malignant behavior (excluding neoplasms of intermediate malignancy, according to the WHO classification, such as solitary fibrous tumors or histiocytomas). Among pleural sarcomas, we identified pleural RIS based on Cahan RIS definition (1):

- there should be a prior history of cancer occurring at least five years before pleural sarcoma occurrence;

- this previous cancer should have been treated with radiation therapy. This information was available in the SEER radiation/chemotherapy database;

- the pleura had to be included in the expected irradiation fields, as is the case for homolateral breast or lung cancers.

Out of 8 million cancer patients from the 18-registry SEER database (1973-2015), 197 malignant pleural sarcoma patients were identified $(0.0024 \%)$. Median age was 66 (3-91). There were 133 (67.5\%) male and 64 (32.5\%) female patients. The most frequent specified histological types were angiosarcomas $(\mathrm{n}=27,13.7 \%)$, synovial sarcomas $(\mathrm{n}=24$, $12.2 \%)$, spindle cell sarcomas $(\mathrm{n}=24,12.2 \%)$ and fibrosarcomas $(n=13,6.6 \%)$.

Address for correspondence: Pierre Loap, Institute Curie, Department of Radiation Oncology, Paris, France, tel: +33 631339838;

e-mail: pierre.loap@gmail.com

This article is available in open access under Creative Common Attribution-Non-Commercial-No Derivatives 4.0 International (CC BY-NC-ND 4.0) license, allowing to download articles and share them with others as long as they credit the authors and the publisher, but without permission to change them in any way or use them commercially 
Of these 197 pleural sarcoma patients, three fulfilled criterions for pleural RIS (Tab. 1). Age at sarcoma diagnosis ranged between 54 and 74 . All patients were women, previously irradiated for homolateral breast cancer. The median latency period before sarcoma occurrence ranged between 14 and 20 years. Surgery was attempted for one patient. Median overall survival was 4 months.

\section{Discussion}

Development of radiation-induced sarcoma occurs in $0.03 \%$ to $0.2 \%$ of post-irradiation follow-up, over a 10-year period [2]. Pleural RIS are exceedingly rare; in addition to the three patients identified in the SEER registry, only one other case has been described [3]: angiosarcoma developed four years after lung irradiation. Treatment may rely on surgery when possible and chemotherapy, but overall survival seems very poor.

All pleural RIS cases from the SEER database occurred after breast radiation therapy; this rare diagnosis should, therefore, be suspected in front of pleural effusion or mass years after homolateral breast radiation-therapy. However, in a cohort of 16,000 breast cancer patients, Kirova et al. found that the most frequent RIS localization were the breast and the chest wall [4]. Interestingly, no pleural RIS were evidenced, despite frequent inclusion of anterior thoracic pleura into tangential radiation fields. Tissue radiation sensitivity differences for sarcoma carcinogenesis could be hypothesized. Current state-of-the-art breast radiation therapy techniques, such as intensity modulated radiation therapy, tend to increase lung and pleura exposure compared with traditional irradiation approaches [5]. Long-term studies focusing on recent radiation therapy techniques will thus be needed to evaluate late pleuro-pulmonary toxicity.

\section{Conflict of interest}

The authors certify that they have no affiliations with or involvement in any organization or entity with any financial interest (such as honoraria; educational grants; participation in speakers' bureaus; membership, employment, consultancies, stock ownership, or other equity interest; and expert testimony or patent-licensing arrangements), or non-financial interest (such as personal or professional relationships, affiliations, knowledge or beliefs) in the subject matter or materials discussed in this manuscript.

\section{Funding}

The authors declare that they have no funding and no financial support.

\section{Data sharing}

Research data are stored in an institutional repository and will be shared upon request to the corresponding author.

\section{References}

1. Cahan $\mathrm{W}$, Woodard $\mathrm{H}$, Higinbotham $\mathrm{N}$, et al. Sarcoma in irradiated bone. Report of eleven cases. Cancer. 1948; 1(1): 3-29, doi: 10.1002/1097-0142(194805)1:1<3::aidcncr2820010103>3.0.co;2-7, indexed in Pubmed: 9428476.

2. Sheth GR, Cranmer LD, Smith BD, et al. Radiationinduced sarcoma of the breast: a systematic review. Oncologist. 2012; 17(3): 405-418, doi: 10.1634/theoncologist.2011-0282, indexed in Pubmed: 22334455.

3. Miller R, Mudambi L, Vial MR, et al. Radiation-induced Angiosarcoma as a Cause of Pleural Effusion. Am J Respir Crit Care Med. 2017; 196(4): e10-e11, doi: 10.1164/ rccm.201702-0442IM, indexed in Pubmed: 28510475.

4. Kirova YM, Vilcoq JR, Asselain B, et al. Radiation-induced sarcomas after radiotherapy for breast carcinoma: a large-scale single-institution review. Cancer. 2005; 104(4): 856-863, doi: $10.1002 /$ cncr.21223, indexed in Pubmed: 15981282.

5. Aznar MC, Duane FK, Darby SC, et al. Exposure of the lungs in breast cancer radiotherapy: A systematic review of lung doses published 2010-2015. Radiother Oncol. 2018; 126(1): 148-154, doi: 10.1016/j.radonc.2017.11.022, indexed in Pubmed: 29246585.

Table 1. Characteristics of pleural radiation-induced sarcomas from the SEER database (1973-2015)

\begin{tabular}{l|c|c|c|c|c|c|c|}
\hline $\begin{array}{l}\text { Diagnosis } \\
\text { year }\end{array}$ & \multicolumn{2}{|c}{ Sex } & Age & Irradiated tumor & Latency & $\begin{array}{c}\text { Pleural RIS } \\
\text { histology }\end{array}$ & Surgery \\
\hline 1995 & Female & 54 & $\begin{array}{c}\text { Right breast invasive } \\
\text { carcinoma }\end{array}$ & 16 years & Fibrosarcoma & No & $\begin{array}{c}\text { Died after } \\
18 \text { months }\end{array}$ \\
\hline 2000 & Female & 74 & $\begin{array}{c}\text { Right breast invasive } \\
\text { carcinoma }\end{array}$ & 14 years & $\begin{array}{c}\text { Spindle cell } \\
\text { sarcoma }\end{array}$ & Yes & $\begin{array}{c}\text { Died after } \\
1 \text { month }\end{array}$ \\
\hline 2014 & Female & 84 & $\begin{array}{c}\text { Left breast invasive } \\
\text { carcinoma }\end{array}$ & 20 years & Synovial sarcoma & No & $\begin{array}{c}\text { Died after } \\
4 \text { months }\end{array}$ \\
\hline
\end{tabular}

